\title{
A NEW SPECIES OF AFROTHISMIA (BURMANNIACEAE; TRIBE: THISMIEAE) FROM THE WESTERN FOOTHILLS OF MOUNT CAMEROON
}

\author{
TH. FRANKE ${ }^{1}$, M.N. SAINGE 2 \& R. AGERER ${ }^{1}$
}

\begin{abstract}
SUMMARY
Afrothismia foertheriana, a new species of Burmanniaceae (tribe: Thismieae) from the peripheral zone of the Onge Forest Reserve in Cameroon's Southwest Province is described and illustrated. The papillose, multicellular floral trichomes, the tepal's erose margins, the small, zygomorphic perianth mouth and the dull purplish brown coloration give A. foertheriana a distinctive appearance within the genus. The species is here assessed as being critically endangered.
\end{abstract}

Key words: Burmanniaceae, Thismieae, Afrothismia foertheriana, Cameroon, conservation, taxonomy.

\section{INTRODUCTION}

All species of the small genus Afrothismia (Burmanniaceae; tribe: Thismieae) are achlorophyllous myco-heterotrophic herbs, receiving all essential nutrients from root colonizing fungi (Leake, 1994; Cheek \& Williams, 1999; Imhof, 1999). Due to this adaptation the plants do not perform photosynthesis and the function of their aerial shoots is restricted to sexual reproduction. Since species of Afrothismia generally produce flowers and fruits during the rainy season, the plants spend most of their life cycle subterraneously and are well hidden from the collector's eye (Cheek \& Williams, 1999; Sainge, 2003).

Afrothismia winkleri (Engl.) Schltr. and A.pachyantha Schltr., the two first described species of this genus, were discovered almost at the same time in Cameroon's Southwest Province (Engler, 1905; Schlechter, 1906). Both type localities are situated along the eastern, respectively south-eastern foothills of Mt Cameroon (4095 m), representing one of the country's most densely populated regions. Recent efforts to find both species in this area failed and brought to light an alarming situation. The natural vegetation around the village of Muea (formerly 'Neu Tegel'), which is the place where H. Winkler collected A. winkleri in 1904 (Engler, 1905), has been completely replaced by banana plantations. The hills around the village of Moliwe, where Schlechter discovered A.pachyantha and another population of A. winkleri in 1905 (Schlechter, 1906), experienced

1) Department Biology I and GeoBio-CenterLMU, Biodiversity Research, Systematic Mycology, Menzinger Str. 67, D-80638 München, Germany; thafra@web.de (author for correspondence); myrrhmyk@1rz.uni-muenchen.de

2) CTFS / BDCPC / Korup Forest Dynamic Plot, Korup National Park, P.O. Box 36, Mundemba, Cameroon; sainge2001@yahoo.com 
the same fate, since most of the area is covered by oil palm and rubber plantations at the present time. The small patches of rain forest still existing on some steep slopes between Moliwe and the village of Saxenhof, as well as the southerly situated BimbiaBonadikombo community forest, were vainly scoured by us for Afrothismia during the rainy seasons of 2000, 2001 and 2002; and by others during 1991-1993 (Cheek \& Ndam 1996; Cable \& Cheek 1997).

Since there remains little hope to find Afrothismia on the east side of Mount Cameroon, another attempt was made on the western foothills in October 2002. The screening was carried out in the peripheral zone of the Onge Forest Reserve close to the village of Diongo. Although neither Afrothismia winkleri nor A. pachyantha could be registered, two different species of Afrothismia were found. One species was identified as the recently described Afrothismia hydra Sainge \& Th. Franke, which also occurs further west in the nearby Korup National Park and Southern Nigeria (Sainge \& Franke, in press). The second species matches none of the seven known species of Afrothismia and will be described below (Engler, 1905; Schlechter, 1906; Cowley, 1988; Maas-van de Kamer, 2003; Cheek, 2003; Franke, 2004; Sainge \& Franke, in press).

Afrothismia foertheriana Th. Franke, Sainge \& Agerer, spec.nov. - Fig. 1, 2

Differt ab specibus ceteris generis floribus obscuri-coloratis (obscure brunnei-purpureis), marginibus tepalorum irregulariter dentatis, tubo perigonii trichomalibus papillosis obtecto, apertura zygomorpha minuta. - Typus: Th. Franke \& M. Sainge 02/030 (holo YA; iso B, WAG), Cameroon, Southwest Province, Ndian Division, Diongo Community Forest, peripheral zone of the Onge Forest Reserve, c. 8 km NE of Diongo village, alt. c. $220 \mathrm{~m}$, 7 Oct. 2002.

Myco-heterotrophic herb. Stem whitish to yellowish, with clusters of proximally inflated roots and few scale-like leaves, sometimes branching, distinctly ribbed, up to 37 $\mathrm{mm}$ long, $1.7 \mathrm{~mm}$ diameter. Proximally inflated part of root yellowish, tubercle-like, ellipsoid to ovoid, $1.6-1.9$ by $1-1.2 \mathrm{~mm}$; distally elongate part of root white, up to 48 $\mathrm{mm}$ long, $0.3 \mathrm{~mm}$ diameter. Leaves scale-like, narrowly triangular, $2.7-5$ by $1.1-2.5$ $\mathrm{mm}$. Inflorescence 1- or 2-flowered. Bracts whitish translucent, faintly purplish brown, broadly triangular, acuminate, $6.7-7.5$ by $5.8-6.6 \mathrm{~mm}$. Flowers sessile, epigynous, zygomorphic; perianth basally fused, forming an inflated tube with six free tepals. Lower part of perianth tube obovoid, ventrally rugose to plicate, with prominent, longitudinally running ribs on the inner wall, whitish translucent, with dark purplish brown stripes alternating with dark purplish brown arrow-head-like marks, converging into a likewise coloured radial band just below the base of the tepals; length of perianth tube 13-15.8 mm, width at widest point $8.3-8.8 \mathrm{~mm}$. Upper part of perianth tube forming an elliptic scutiform plate girded by the tepal bases, glossy, whitish translucent, speckled with purplish brown dots and lines, $8.3-8.8$ by $7.3-7.5 \mathrm{~mm}$, marginally set with multicellular, papillose trichomes, $0.3-1.6 \mathrm{~mm}$ in length. Mouth strongly zygomorphic, inserted within the upper third of the perianth plate, obovate surrounded by a velvety rim with roof-like projecting upper half, $1.8 \mathrm{~mm}$ at widest point; upper part of perianth tube provided with an internal, marginally densely papillose flange, up to $2.3 \mathrm{~mm}$ wide, ventrally declining in width. Tepals pointing straight forwards, distally approaching each other, similar in shape and length, each tepal with erose membranaceous, whitish translucent margins basally converging into distinctly fringed extensions, dark purplish 

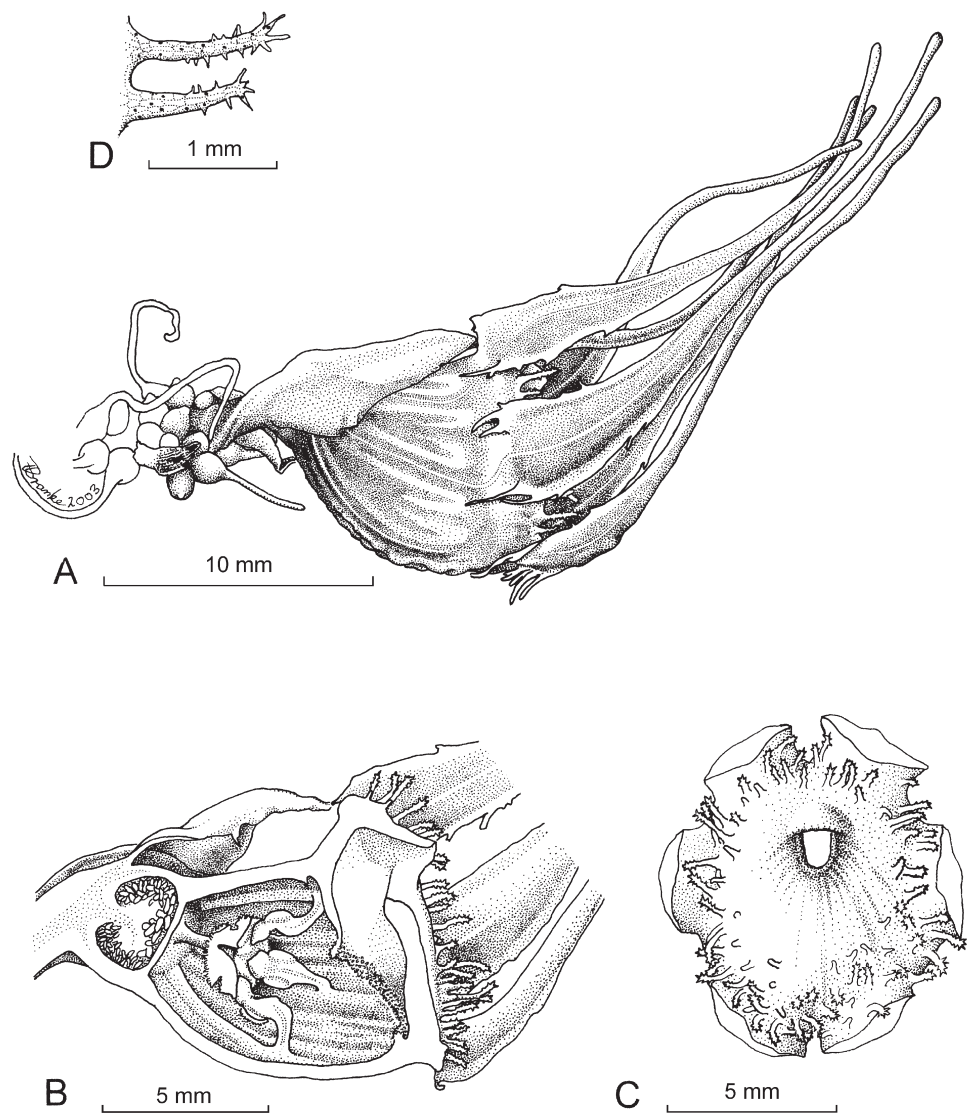

Fig. 1. Afrothismia foertheriana Th. Franke, Sainge \& Agerer. A. Lateral view of flower; B. longitudinally dissected flower, showing internal structures of perianth tube; $\mathrm{C}$. frontal view of flower (tepals removed); D. multicellular, papillose trichomes (all: Th. Franke \& M. Sainge 02/030). Drawn by Th. Franke.

brown, $20-22.7$ by $3.3-4 \mathrm{~mm}$ (width measured at the base), basal extensions $2.4-2.6$ $\mathrm{mm}$ long. Stamens 6, inserted at the base of perianth tube; basal part of filaments $4 \mathrm{~mm}$ adnate to perianth tube, upper part of filaments free, club-shaped, reflexed, 1.8 by 0.4 $\mathrm{mm}$; anthers 1.2 by $1.3 \mathrm{~mm}$, touching the stigma with an apical lobate connective appendage; thecae dehiscing longitudinally, half-way sunken into the fleshy connective, facing towards the perianth wall; connective appendage deltoid, densely papillose, 0.7 by $0.8 \mathrm{~mm}$. Ovary unilocular, white, with a band of 6 purplish brown dots, subspherical, partly enclosed by clasping bract, $1.8-2.6$ by $3.3-3.8 \mathrm{~mm}$; placentas 3 , in their basal part connate into a central sterile column, in the upper part free and bearing numerous ovules. Style glabrous, 1.4 by $0.5 \mathrm{~mm}$; stigma subspherical, densely papillose, 1.2 by $2.9 \mathrm{~mm}$, consisting of three stigmatic lobes fused to each other. Fruit a pyxidium, 3.8 by $5.8 \mathrm{~mm}$, sterile column enormously distending, $10.8-14.6$ by $2.2-2.7 \mathrm{~mm}$, pushing aside the lid-like receptacle, lifting the seeds above the fruit bottom. Seeds longellipsoid with loose reticulate testa, $0.5-0.6$ by $0.3 \mathrm{~mm}$. 
Distribution - Cameroon: western foothills of Mt Cameroon.

Habitat \& Ecology - The new species is known only from a single locality, which is situated on a narrow terrace, nestled into a steep slope, covered by open canopy forest. The vegetation was composed of small trees and treelets, tall monocotyledonous herbs and scattered larger trees. A brief plant inventory yielded the following woody plant species: Antidesma vogelianum Müll.Arg., Cola flavo-velutina K. Schum., Craterispermum aristatum Wernham, Dicranolepis disticha Planch., Dicranolepis spec., Diospyros cinnabarina (Gürke) F. White, Diospyros preussii Gürke, Diospyros suaveolens Gürke, Diospyros spec. 1 and spec. 2, Jollydora duparquetiana (Baill.) Pierre, Lasianthera africana P. Beauv., Maesobotrya dusenii (Pax) Pax, Massularia acuminata (G. Don) Bullock ex Hoyle, Microdesmis puberula Hook.f. ex Planch., Octoknema affinis Pierre, Pycnanthus angolensis (Welw.) Warb., Rhabdophyllum cf. calophyllum (Hook.f.) Tiegh., Rinorea subintegrifolia (P. Beauv.) Kuntze, Scyphocephalium mannii (Benth.) Warb., Strombosia grandiflora Hook.f. ex Benth., Strombosia pustulata Oliv., Tapura africana Oliv., Trichoscypha spec. In contrast to most other myco-heterotrophic plants, which usually occur in company with different likewise myco-heterotrophic species, A.foertheriana was growing solitarily. The only other myco-heterotrophic plants that were found in the more distant surroundings were Afrothismia hydra, Burmannia congesta (Wright) Jonker, Burmannia hexaptera Schltr., Gymnosiphon cf. longistylus (Benth.) Hutch. \& Dalziel; Kupea martinetugei Cheek \& S.A. Williams, Sciaphila ledermannii Engl. and Sebaea oligantha (Gilg) Schinz.

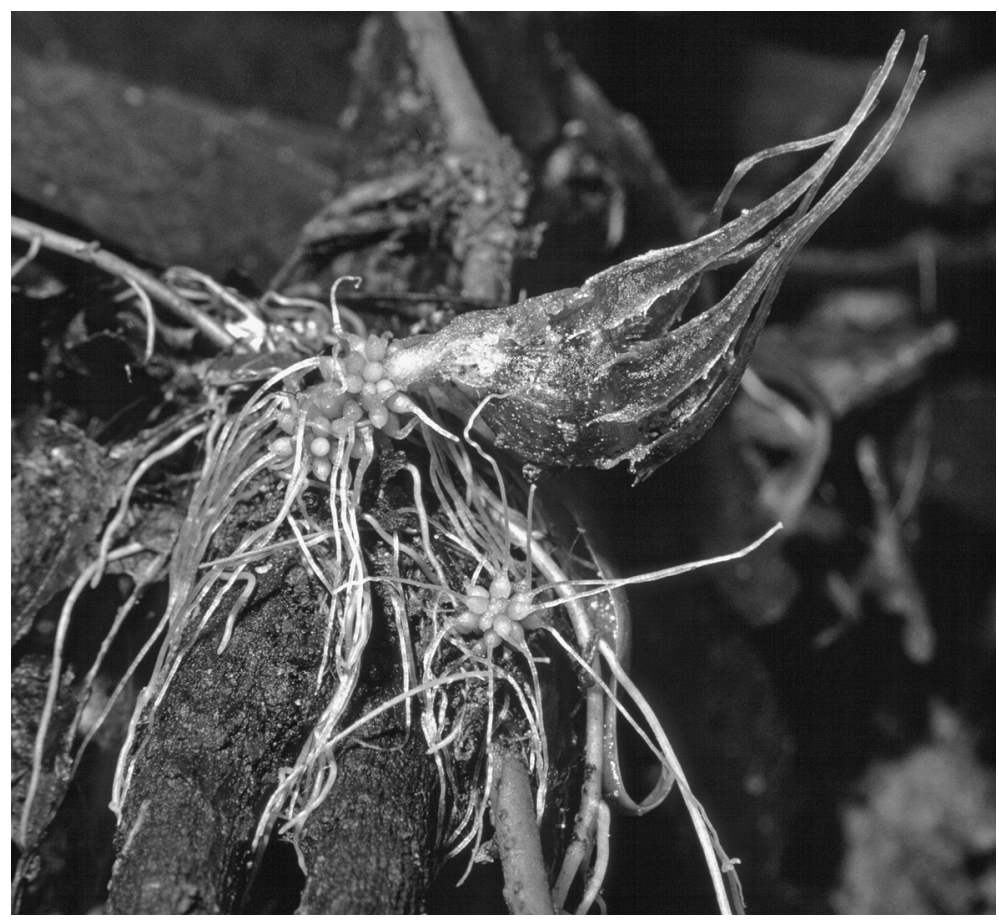

Fig. 2. Afrothismia foertheriana Th. Franke, Sainge \& Agerer. Habit. Photograph by Th. Franke (Th. Franke \& M. Sainge 02/030). 
Afrothismia foertheriana was growing in groups of scattered individuals, showing an obvious preference for raised microhabitats, e.g. horizontally running tree roots (Fig. 2). In some cases, the rhizomes and most roots were exposed to the air with only the distal parts of the filiform roots entering the uppermost soil strata (Fig. 2). Since the great majority of individuals were in the fruiting phase when discovered in October, it seems likely that the peak of the flowering season is around August/September.

Etymology - The specific epithet honours my (T.F.) colleague and friend Harald Förther, to whom I am much indebted for his constant readiness to help and advise me during my educational career.

Note - The type locality of Afrothismia foertheriana belongs to the Lower Guinean regional subcentre of endemism and is part of the Western Cameroon mountain glacial refuge sub-area, which is one of the richest plant diversity centres in Africa (Morton, 1972; White, 1979; Beentje et al., 1994; Sosef, 1994; Mutke et al., 2001). Many of the species in this region are highly endemic and for this reason seriously threatened by human impact. Hence, the conservation status of Afrothismia foertheriana is assessed as CR B1 [a, b (iii)] following the guidelines of the IUCN (2001). In other words, the species is believed to be critically endangered because its geographic range is estimated to less than $100 \mathrm{~km}^{2}$ and because it is known only from a single location, where it is severely threatened by illegal logging and the extent of agricultural activities (mainly oil palm and cocoa cultivation).

\section{ACKNOWLEDGEMENTS}

This study was financially supported by the BIOLOG (Biodiversity and Global Change) programme (Grant 01LC0007) of the German Ministry of Education and Research (BMBF). L. Beenken and D. Podlech / LMU München are thanked for constructive discussions and the Latin diagnosis. Furthermore, the authors are greatly indebted to the people of Diongo and the guides Mambo and Robert for their warm hospitality and constant support in the field.

\section{REFERENCES}

Beentje, H.J., B. Adams \& S.D. Davies. 1994. Regional Overview: Africa. In: S.D. Davies, V.H. Heywood \& A.C. Hamilton (eds), Centres of Plant Diversity, Vol. 1: 101-148. WWF \& IUCN.

Cable, S. \& M. Cheek. 1997. The plants of Mount Cameroon, a conservation checklist. Royal Botanic Gardens, Kew.

Cheek, M. 2003. A new species of Afrothismia (Burmanniaceae) from Kenya. Kew Bulletin 58: 951-955.

Cheek, M. \& N. Ndam. 1996. Saprophytic flowering plants of Mount Cameroon. In: L.J.G. van der Maesen et al. (eds), The Biodiversity of African Plants: 612-617. Kluwer Academic Publishers, The Netherlands.

Cheek, M. \& S. Williams. 1999. A review of African saprophytic flowering plants. In: J. Timberlake \& S. Kativu (eds), African plants: biodiversity, taxonomy and uses. Proceedings of the 1997 AETFAT congress, Harare, Zimbabwe: 39-49. Royal Botanic Gardens, Kew.

Cowley, E.J. 1988. Burmanniaceae. In: R.M. Polhill (ed.), Flora of Tropical East Africa: 1-9. Balkema, Rotterdam, Brookfield.

Engler, A. 1905. Thismia winkleri Engl., eine neue afrikanische Burmanniaceae. Bot. Jahrb. Syst. 38: 89-91.

Franke, Th. 2004. Afrothismia saingei (Burmanniaceae), a new myco-heterotrophic plant from Cameroon. Syst. Geogr. Pl. 74: 27-33. 
Imhof, S. 1999. Anatomy and mycotrophy of the achlorophyllous Afrothismia winkleri. New Phytol. 144: 533-540.

IUCN. 2001. IUCN Red List Categories and Criteria: Version 3.1. IUCN Species Survival Commission. IUCN, Gland, Switzerland \& Cambridge, UK.

Leake, J.J. 1994. The biology of myco-heterotrophic ('saprophytic') plants. Tansley Review No. 69. New Phytol. 127: 171-216.

Maas-van de Kamer, H. 2003. Afrothismia gesneriodes, another new species of Afrothismia (Burmanniaceae) from tropical Africa. Blumea 48: 475-478.

Morton, J.K. 1972. Phytogeography of the West African Mountains. In: D.H. Valentine (ed.), Taxonomy, Phytogeography and Evolution: 221-236. Academic Press, London.

Mutke, J., G. Kier, G. Braun, Chr. Schulz \& W. Barthlott. 2001. Patterns of African vascular plant diversity - a GIS based analysis. Syst. Geogr. Pl. 71: 1125-1136.

Sainge, M.N. 2003. Studies on the phenology of African myco-heterotrophic plants (abstract). In: U. Karlowski, P. Kiehl, T. Lemke, T. Pitsch \& R. Paschen (eds), Tagungsband der 16. Jahrestagung der Gesellschaft für Tropenökologie: 66. Rostock, Germany.

Sainge, M.N. \& Th. Franke. In press. A new species of Afrothismia (Burmanniaceae) from Cameroon. Nordic J. Bot.

Schlechter, R. 1906. Burmanniaceae africanae. Bot. Jahrb. Syst. 38: 137-143.

Sosef, M.S.M. 1994. Refuge Begonias. Taxonomy, phylogeny and historical biogeography of Begonia sect. Loasibegonia and sect. Scutibegonia in relation to glacial rain forest refuges in Africa. $\mathrm{PhD}$ thesis. Wageningen.

White, F. 1979. The Guineo-Congolean Region and its relationships to other phytochoria. Bull. Jard. Bot. Belg. 49: 11-45. 